\title{
SUSTAINABILITY ANALYSIS OF WHITELEG SHRIMP POND AQUACULTURE AT JATIRENGGO VILLAGE, LAMONGAN REGENCY
}

\author{
Evellin Dewi Lusiana ${ }^{1}$, Muhammad Musa ${ }^{2}$, Mohammad Mahmudi ${ }^{3}$, Sulastri \\ Arsad $^{4}$, Nanik Retno Buwono ${ }^{5}$ \\ ${ }^{1}$ Faculty of Fisheries and Marine Science, Brawijaya University, Malang, Indonesia \\ ${ }^{2}$ AquaRES Research Group, Brawijaya University, Malang
}

\begin{abstract}
Whiteleg shrimp (Litopenaeus vannamei) is a fisheries commodity which has high economic value because of its high demand and easier cultivation. Lamongan regency is one of the minapolitan region in East Java Province, especially at Glagah district, Jatirenggo village which becomes the minapolist, with one of the superior commodities is whiteleg shrimp. The development of a certain village can be determined by village developing index or IDM which consists of three categories, they are left behind, developing, and advance village. Jatirenggo village has a village developing index (IDM) of 0.6080 which classified as developing category or category 2. Thus, in order to increase its status, the welfare of its people need to be considered. Whiteleg shrimp pond aquaculture can be one of the effort to increase the income of Jatirenggo's. This study aims to analyze the sustainability of whiteleg shrimp aquaculture activity in Jatirenggo village according to ecology, socio-economic, technology-infrastructure, and institutional dimension. The used method was MDS Rapfish. The results showed that the whiteleg shrimp aquaculture in Jatirenggo village is classified as sustainable, or it means the situation in Jatirenggo village is suitable for a successful aquaculture. Thus, it can be expected to increase the income of the farmers.

Keywords: whiteleg shrimp, aquaculture, sustainability, MDS-Rapfish
\end{abstract}

\section{INTRODUCTION}

Whiteleg shrimp (Litopenaeus vannamei) or also known as Pacific White Shrimp is an introduced species which has high economics value because of its high demand. This species got into Indonesia in 2001 and started to be cultivated in aquaculture pond at Banyuwangi and Situbondo region, along with the decreasing production of tiger shrimp as the consequence of White Spot Syndrome Virus (Sugama, 2002).

The advantages of whiteleg shrimp are its high growth rate, resist to disease, and has high tolerance to the environmental change(Widodo \& Dian, 
Sustainability Analysis ...... (Evellin Dewi Lusiana ${ }^{1}$, Muhammad Musa ${ }^{2}$, Mohammad Mahmudi $^{3}$, Sulastri Arsad ${ }^{4}$, Nanik Retno Buwono ${ }^{5}$ )

2005). Beside, Briggs et al. (2004) also stated that its stock density is relatively high up to 150 heads $/ \mathrm{m}^{2}$, wide range salinity tolerance $(0.5-45 \mathrm{ppt})$, low protein needs $(20 \%-30 \%)$ and better food conversion ratio $(1.2<\mathrm{FCR}<1.6)$.

Lamongan regency is one of the minapolitan region in East Java Province, especially at Glagah district which becomes the core sector or minapolist, with one of the superior commodities is whiteleg shrimp. In this region, the production of whiteleg shrimp is always increasing by average $1.89 \%$ per year. At 2014, whiteleg shrimp total production is 13,856 tons (KKP, 2014).

One of the village in Glagah district that focuses on whiteleg shrimp aquaculture activity is Jatirenggo village. However, according to Ministry of Villages, Development of Disadvantaged Areas and Transmigration data on 2015, the village developing index or IDM of Jatirenggo district is 0.6080 which in still developing category (category 2).
The criteria of IDM is based on several aspects such as poverty, human resources quality, infrastructures, financial ability, accessibility to infrastructures, social conflicts and natural disasters (Muhtar et al., 2011; Soetomo, 2006). Thus, one of the effort to increase Jatirenggo village's IDM can be through fisheries sector, especially whiteleg shrimp aquaculture pond.

The aquaculture pond process to produce whiteleg shrimp in Jatirenggo village classified as traditional pond. It means highly dependent on nature and farmers instinct. As the consequence, Whiteleg shrimp farmers in Jatirenggo village, the shrimp's size is not uniform, high mortality rate as the result of disease and bad water quality management so that its survival rate is low (Arsad et al., 2017).

Those conditions need to be considered so that the aquaculture activity of Whiteleg shrimp will sustain, and increase the development 
Sustainability Analysis ...... (Evellin Dewi Lusiana ${ }^{1}$, Muhammad Musa ${ }^{2}$, Mohammad Mahmudi $^{3}$, Sulastri Arsad ${ }^{4}$, Nanik Retno Buwono ${ }^{5}$ )

index of the village. Thus, the purpose of this article is to study the sustainability status of Whiteleg shrimp aquaculture pond activity in Jatirenggo village based on ecology, economic, socio-cu (Pitcher \& Preikshot, 2001) cultural and institutional dimension.

\section{RESEARCH METHODS}

The research is part of the community service at Jatirenggo village, Lamongan regency, East Java province and conducted in October 2017. The data is collected by survey method through structured interview using closed questionnaire. The respondents are whiteleg shrimp farmers in Jatirenggo village who joined in Mina Nusantara farmer group as many as 25 respondents.

The data analysis to identify sustainability status of whiteleg shrimp aquaculture pond is utilizing MultiDimensional Scaling (MDS) with Rapfish approach. According to Pitcher dan Preikshot (2001), the evaluation of sustainability can be done by applying 3 to 5 dimensions such as ecology, economic, institutional, technology, and social. Those dimensions are described into several attributes which reflected the sustainability and adjusted with the availability of information source at the desired area. This research utilized ecology, socio-economic, technologyinfrastructure and institutional dimension with each attributes as follows:

1. Ecology dimension

a. Availability of land

b. Water quality and soil for cultivation are supportive

c. The survival rate of shrimp

d. Shrimp disease

e. Climate change

2. Socio-economic dimension
a. Venture capital
b. Marketing
c. Feed cost
d. Market demand for whiteleg shrimp
e. The selling price of shrimp 
Sustainability Analysis ...... (Evellin Dewi Lusiana ${ }^{1}$, Muhammad Musa ${ }^{2}$, Mohammad Mahmudi $^{3}$, Sulastri Arsad ${ }^{4}$, Nanik Retno Buwono ${ }^{5}$ )

f. Availability of micro credit for business development

g. The farmers have long been experienced in vaname shrimp cultivation

h. Education level

i. Selling price fluctuation

3. Technology and infrastructure dimension

a. Society openness to accept innovation

b. Water quality instrument

c. Limited knowledge of shrimp cultivation

d. Some farmers have been into semi-intensive

e. Market demands related to the quality of shrimp that are free of chemicals / preservatives

4. Institutional dimension
a. Availability
of
group
organizational structure

b. The group of shrimp farmers are compact and help each other

c. Routine group member meetings are held
d. Problem solving through discussion
e. Local government supporting
f. Coaching and mentoring activities by related agencies are routinely carried out
g. Community service activities are often carried out by the University

\section{Goodness-of-fit MDS-Rapfish}

Goodness-of-fit of MDSRapfish is aimed to assess that the sustainability index that resulted from the analysis can be accounted for. The evaluation is conducted by measuring the S-stress. S-stress is a numeric measure between origin point and estimation point that calculated using least square method. The formula of Sstress is denoted by equation (1).

$$
S-\text { stress }=\sqrt{\frac{1}{m} \sum_{k=1}^{m} \frac{\sum_{i} \sum_{j}\left(d_{i j k}^{2}-O_{i j k}^{2}\right)^{2}}{\sum_{i} \sum_{j} O_{i j k}^{4}}}
$$

where

$\mathrm{d}_{\mathrm{ijk}}=$ Euclidean distance

$\mathrm{O}_{\mathrm{ijk}}=$ Estimated Euclidean distance

$\mathrm{m}=$ number of attributes 
Sustainability Analysis ...... (Evellin Dewi Lusiana ${ }^{1}$, Muhammad Musa ${ }^{2}$, Mohammad Mahmudi $^{3}$, Sulastri Arsad ${ }^{4}$, Nanik Retno Buwono ${ }^{5}$ )

If the S-stress is less than 0.25 , it means good fit, otherwise poor fit. Beside Sstress, another goodness-of-fit criteria is R-square. In which, the desirable value of $\mathrm{R}$-square is greater than 0.90 (Susilo, 2003).

Moreover, leverage score is used to identify which attributes that have high sensitivity to the sustainability status. These attributes will become the focus point of the strategy in order to increase the sustainability index (Fauzi \& Anna, 2005).

\section{Assessing Sustainability Status}

Pitcher dan Preikshot (2001) mapped sustainability of attributes each dimension into bad point (bad-down) and good point (good-up). Classification of sustainability status is presented in Table 1.

Table 1 Sustainability Status Category

\begin{tabular}{ccc}
\hline No. & Index & Category \\
\hline 1 & $0-25$ & Bad sustainable \\
\hline 2 & $25-50$ & Less sustainable \\
\hline 3 & $50-75$ & Sustainable \\
\hline 4 & $>75$ & $\begin{array}{c}\text { Good } \\
\text { sustainable }\end{array}$ \\
\hline
\end{tabular}

\section{RESULT AND DISCUSSIONS}

The result of goodness-of-fit calculation for MDS-Rapfish analysis is displayed in Table 2.

Table 2 Summary Goodness-of-fit MDS-Rapfish Analysis

\begin{tabular}{lcc}
\hline \multicolumn{1}{c}{ Dimension } & $\begin{array}{c}\text { Stress } \\
(S)\end{array}$ & $\begin{array}{c}\text { R-Square } \\
(R)\end{array}$ \\
\hline Ecology & 0.2185 & 0.9330 \\
\hline $\begin{array}{l}\text { Socio- } \\
\text { economic }\end{array}$ & 0.2297 & 0.9276 \\
\hline $\begin{array}{l}\text { Technology } \\
\text { and } \\
\text { infrastructure }\end{array}$ & 0.2403 & 0.9260 \\
\hline Institutional & 0.2211 & 0.9314
\end{tabular}

Source: Add-ins Ms. Excel Rapfish, 2018

According to Table 1, S-Stress value of the four dimensions are less than 0.25 and the R-squares are more than 0.90 . It means that the result of MDS-Rapfish analysis can be accounted or veritable.

Since the criteria for goodnessof-fit is fulfill, then the analysis to assess sustainability status for each dimension.

\section{Ecology Dimension}

The following Figure 1 and 2 showing the sustainability index and

Source: Pitcher dan Preikshot (2001) 
Sustainability Analysis ...... (Evellin Dewi Lusiana ${ }^{1}$, Muhammad Musa ${ }^{2}$, Mohammad Mahmudi $^{3}$, Sulastri Arsad ${ }^{4}$, Nanik Retno Buwono ${ }^{5}$ )

attributes sensitivity of ecology dimension respectively.

Figure 1 Sustainability Index for Ecology Dimension

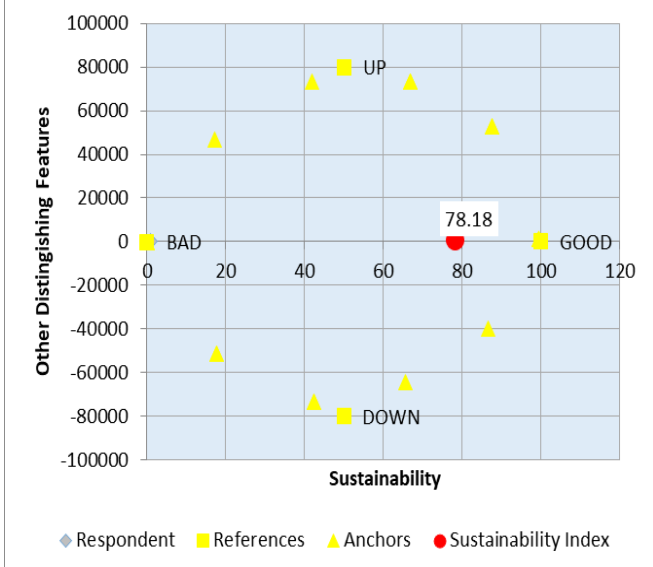

Source: Add-ins Ms. Excel Rapfish, 2018

Figure 1 shows that the sustainability status for ecology dimension is 78.18 or classified as sustain. Thus, the ecological state in Jatirenggo village is very supporting the Whiteleg shrimp pond aquaculture.

Figure 2 Attributes Sensitivity for Ecology Dimension

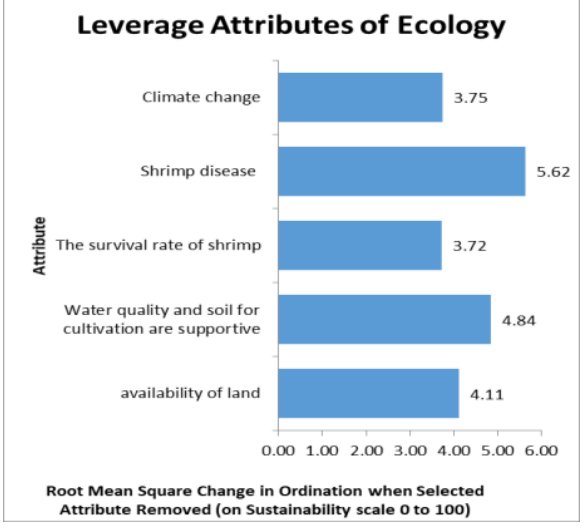

Source: Add-ins Ms. Excel Rapfish, 2018
Based on Figure 2, shrimp disease issue, water and soil quality for cultivation need to be considered since its leverage for sensitivity is the highest.

\section{Socio-Economic Dimension}

The sustainability index and attributes sensitivity are presented in Figure 3 and 4.

Figure 3 Sustainability Index for Socio-Economic Dimension

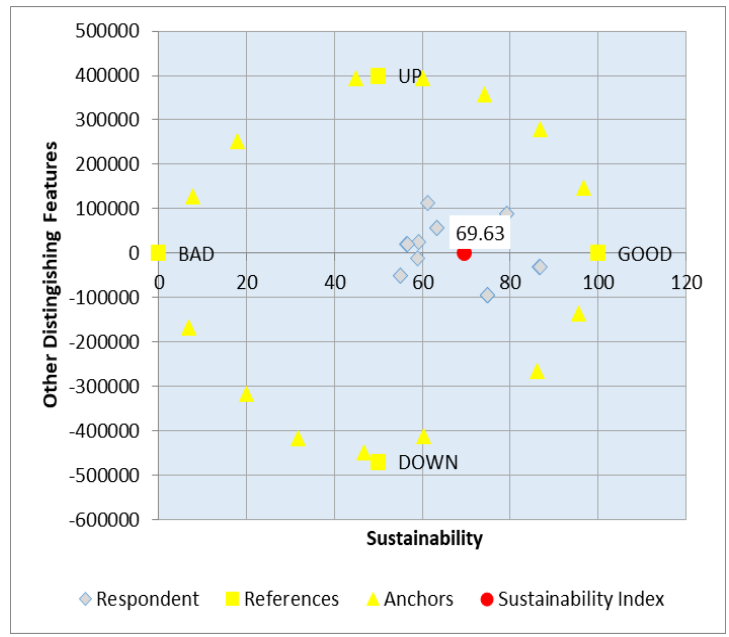

Source: Add-ins Ms. Excel Rapfish, 2018

Figure 3 presents the sustainability status of the socioeconomic dimension for Whiteleg shrimp pond aquaculture is sustain enough. 
Sustainability Analysis ...... (Evellin Dewi Lusiana ${ }^{1}$, Muhammad Musa ${ }^{2}$, Mohammad Mahmudi $^{3}$, Sulastri Arsad ${ }^{4}$, Nanik Retno Buwono ${ }^{5}$ )

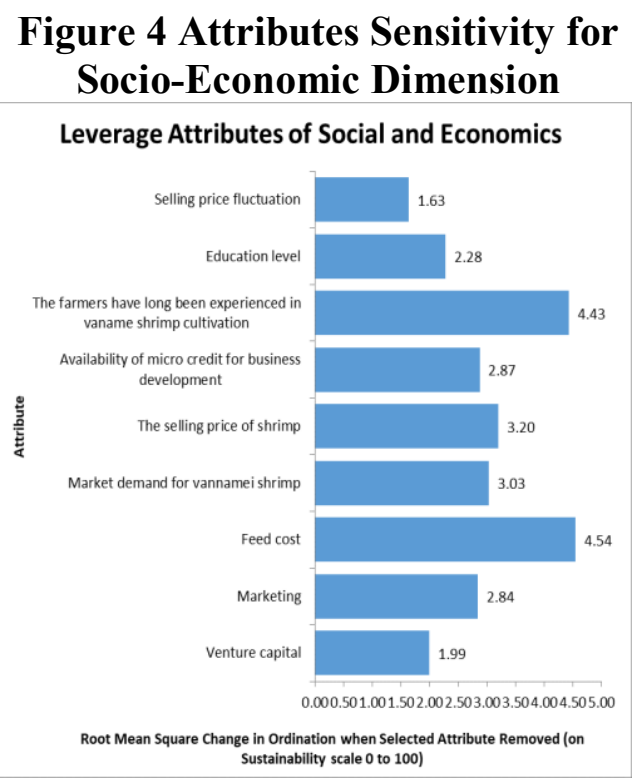

Source: Add-ins Ms. Excel Rapfish, 2018

The sustainability status of socio-economic dimensio can be increased by giving more attention to the attributes which have high leverage as in Figure 4. The attributes are farmers' experience in Whiteleg shrimp aquaculture and the high cost of feed.

\section{Technology and Infrastructure Dimension}

As for the sustainability index and attributes sensitivity for technology and infrastructure dimension are displayed in Figure 5 and 6.
Figure 5 Sustainability Index for Technology and Infrastructure Dimension

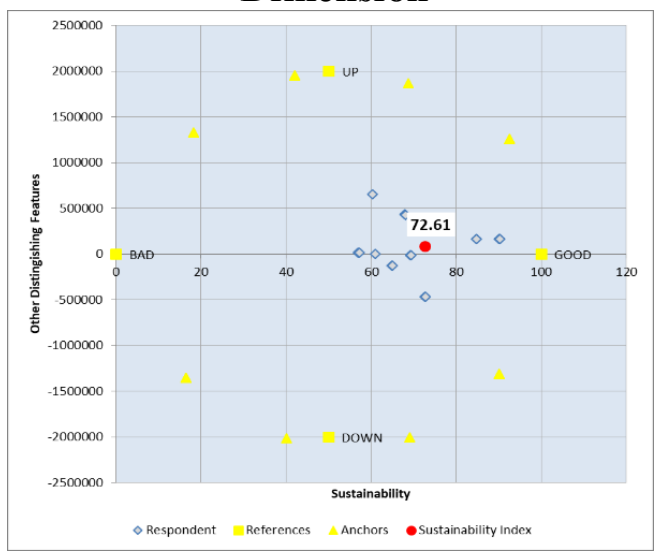

Source: Add-ins Ms. Excel Rapfish, 2018

Figure 5 shows that the sustainability status of technology and infrastructure dimension is classified as sustain. Or in other words, the infrastructure in Jatirenggo village is relatively enough to support the Whiteleg shrimp pond aquaculture.

Figure 6 Attributes Sensitivity for Technology and Infrastructure

\section{Dimension}

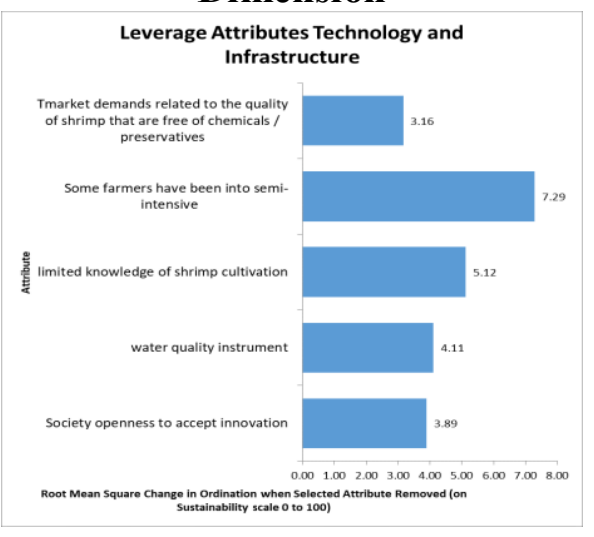

Source: Add-ins Ms. Excel Rapfish, 2018 
Sustainability Analysis ...... (Evellin Dewi Lusiana ${ }^{1}$, Muhammad Musa ${ }^{2}$, Mohammad Mahmudi $^{3}$, Sulastri Arsad ${ }^{4}$, Nanik Retno Buwono ${ }^{5}$ )

According to Figure 6, the disadvantage of technology and infrastructure dimension is less farmers who is using semi-intensive method, which resulted the production is not optimum

\section{Institutional Dimension}

Figure 7 and 8 are showing the sustainability index and attributes sensitivity of institutional dimension as follows.

\section{Figure 7 Sustainability Index for Institutional Dimension}

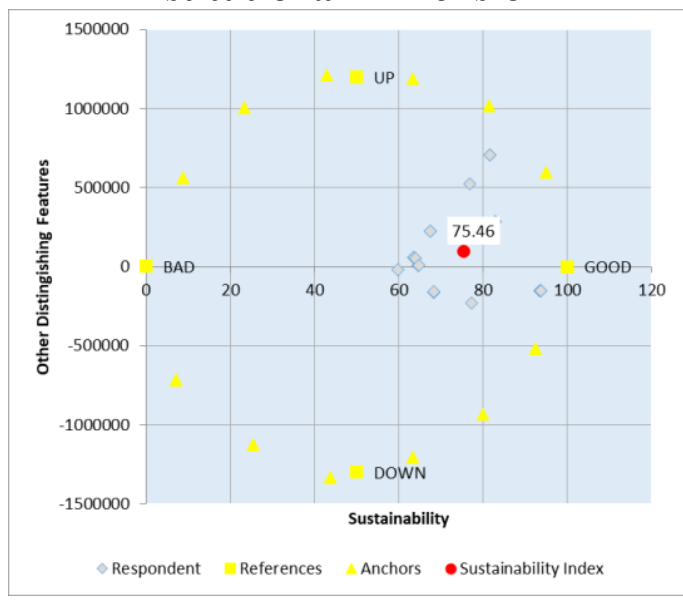

Source: Add-ins Ms. Excel Rapfish, 2018

Figure 7 presents that sustainability status for institutional dimension is categorized as sustain. It is indicated that the community, government, related agency and academic institution relatively support the Whiteleg shrimp aquaculture pond activity in Jatirenggo village.

Figure 8 Attributes Sensitivity for Intitutional Dimension

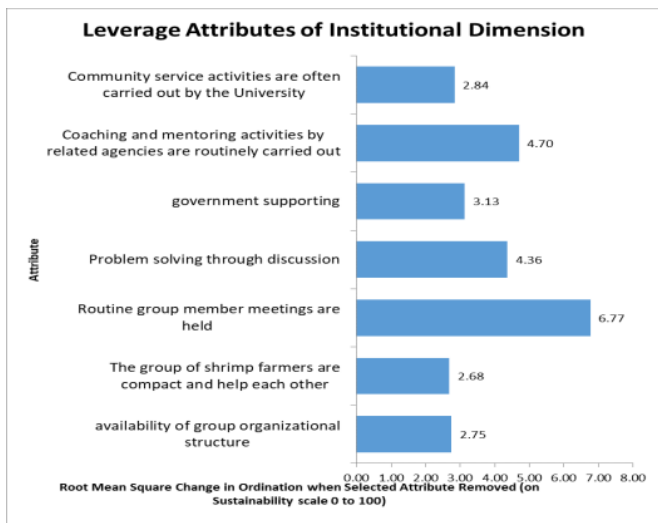

Source: Add-ins Ms. Excel Rapfish, 2018

Figure 8 is giving note that the meeting in farmers group and coaching or mentoring activities by related agency are needed to be held routinely, since their leverage/sensitivity scores are the highest.

\section{Figure 9 Kite Diagram of Sustainability Analysis}

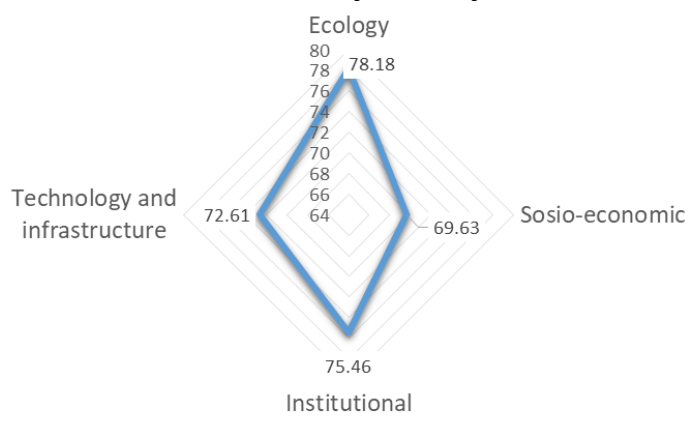

Source: Add-ins Ms. Excel Rapfish, 2018 
Sustainability Analysis ...... (Evellin Dewi Lusiana ${ }^{1}$, Muhammad Musa ${ }^{2}$, Mohammad Mahmudi $^{3}$, Sulastri Arsad ${ }^{4}$, Nanik Retno Buwono ${ }^{5}$ )

Figure 9 presents that the sustainability status of all the used dimension is relatively balance. The overall sustainability status of whiteleg shrimp pond aquaculture in Jatirenggo village is classified as sustainable with the index as many as 73.97. The most sustainable dimension is ecology, awhile the least one is socio-economic dimension. It means that the environment and ecological status in Jatirenggo village is very suitable for the aquaculture activity. So, no wonder that the area (Glagah district) is becoming the minapolist of Whiteleg shrimp (KKP, 2014).

On the other hand, the less advantage dimension is socioeconomic, with the biggest obstacle is less experience of the farmers and high feed cost. Because of the high cost of feed, many farmers in Jatirenggo village are mostly giving natural feed for the Whiteleg shrimp so that the production yield is not optimum. Thus, to resolve this problem, the farmers needed to be educated and trained how to make standalone feed to reduce the cost of feeding.

\section{CONCLUSIONS}

From all the results and discussion, it can be concluded that sustainability is of whiteleg shrimp pond aquaculture at Jatirenggo Village is classified into sustainable, where the most sustain dimension is ecology dimension and the least one is socioeconomic dimension. So that, the situation in Jatirenggo Village is generally suitable for the whiteleg shrimp aquaculture activity in order to increase the welfare of its people.

\section{ACKNOWLEDGEMENT}

This study was conducted as the part of community service which funded through the University of Brawijaya Doktor Mengabdi (DM) in 2017. The authors would like to thank all those who helped complete the research. 
Sustainability Analysis ...... (Evellin Dewi Lusiana ${ }^{1}$, Muhammad Musa ${ }^{2}$, Mohammad Mahmudi $^{3}$, Sulastri Arsad ${ }^{4}$, Nanik Retno Buwono ${ }^{5}$ )

\section{REFERENCES}

Arsad, S., Afandy, A., Purwadhi, A. P., Maya, B., Saputra, D. K., \& Buwono, N. R. 2017. Studi kegiatan budidaya pembesaran udang vaname (Litopenaeus vannamei) dengan peneran sistem pemeliharaan berbeda. Jurnal Ilmiah Perikanan dan Kelautan, 9(1): 1-14.

Briggs, M., Smith, S. F., Subanghe, R., \& Phillips, M. 2004. Introduction and Movement of Penaeus vannamei and $\mathrm{P}$. stylirostis in Asia and the Pacific: 40. Bangkok.

Fauzi, A., \& Anna, S. 2005. Pemodelan Sumberdaya Perikanan dan Kelautan. Jakarta: PT. Gramedia Pustaka Utama.

KKP. 2014. Minapolitan Budidaya di Kabupaten Lamongan.

Muhtar, Sutaat, Achmadi, J. P., Subaedi, A., \& Suyanto. 2011. Masyarakat Desa Tertinggal: Kebutuhan, Permasalahan, Aset, dan Konsep Model Pemberdayaannya(Studi di Desa Jambu, Engkangin, Sendangmulyo \& Mlatirejo). Jurnal Penelitian dan
Pengembangan Penelitian

Sosial, 16(1).

Pitcher, T. J., \& Preikshot, D. 2001. RAPFISH: a rapid appraisal technique to evaluate the sustainability status of ®sheries. Fisheries reserach, 49: 255-277.

Soetomo. 2006. Strategi-Strategi Pembangunan Masyarakat. Yogyakarta: Pustaka Pelajar.

Sugama, K. 2002. Status, Masalah Dan Alternatif Pemecahan Masalah Pada Pengembangan Budidaya Udang Vaname (Litopenaeus Vannamei) Di Sulawesi Selatan, Temu Bisnis Udang. Makassar: Media Akuakultur.

Susilo, S. B. 2003. Keberlanjutan Pembangunan Pulau-pulau Kecil: Studi Kasus Keluarahan Pulau Panggang dan Pulau Pari, Kepulauan Seribu, DKI Jakarta. Institut Pertanian Bogor, Bogor.

Widodo, R. H., \& Dian, A. S. 2005. Udang vannemi: Pembudidayaan dan Prospek Pasar Udang Putih yang Tahan Penyakit. Jakarta: Penebar Swadaya. 